\title{
ПРОБЛЕМИ ФОРМУВАННЯ СВІТОГЛЯДУ ЛІКАРІВ ТА НОВІ НАПРЯМКИ ПІСЛЯДИПЛОМНОЇ МЕДИЧНОЇ ОСВІТИ В УКРАЇНІ
}

\author{
К. А. Зайцева, В. С. Василик, П. С. Жученко
}

Вінницький національний медичний університет імені М. І. Пирогова

\section{PROBLEMS OF DOCTORS' WORLDVIEW FORMING AND NEW DIRECTIONS OF POST-GRADUATE MEDICAL EDUCATION IN UKRAINE}

\author{
K. A. Zaytseva, V. S. Vasylyk, P. S. Zhuchenko \\ Vinnytsia National Medical University by M. I. Pyrohov
}

\begin{abstract}
Проаналізовано сучасні підходи до формування світогляду спеціалістів-медиків і нові технології післядипломної медичної освіти в Україні. Наголос зроблено на необхідності уникання асистенціалізму (якщо він мас місце експліцитно чи імпліцитно).
\end{abstract}

There were analyzed the modern approaches to world view forming in medical professionals and new technologies for postgraduate medical education in Ukraine. An emphasis is laid on the necessity of assistentcialism avoiding (if it takes place explicitly or implicitly).

Вступ. Основним світоглядним принципом вищої медичної освіти в будь-якій сучасній розвинутій країні $€$ те, що вона повинна забезпечувати баланс між навчанням та можливістю самостійно розвивати практичні знання в обраній галузі, а також не копіювати надбання науково-практичних шкіл інших країн у процесі інноваційної або реформаторської діяльності. Цей світоглядний принцип $є$ універсальним принципом, який не втрачає актуальності для представників української вищої медичної освіти на сучасному етапі.

Основна частина. Впродовж останніх років впровадження змін сучасного освітнього та наукового простору України відбувалося в світлі принципів, задекларованих у Болонській декларації (Болонья, Італія, 1999), базових Зальцбурзьких принципів досліджень найвищого рівня /докторантських/, що були визначені на Болонському семінарі “Докторські програми для європейського суспільства знань” (Doctoral programmes for the European knowledge society, Зальцбург, Австрія, 2005 р.); документа “Докторські програми в європейських університетах" (Doctoral Programmes in Europe's universities, 2005 р.), який був створений Свропейською асоціацією університетів за мандатом від Бергенської конференції міністрів освіти і науки європейських країн. Окресливши стратегічні напрямки роботи європейських країн (а не тільки країн Євросоюзу) щодо підвищення інтеропе- рабельності (сумісності) систем охорони здоров'я в них, означені документи в жодному разі не заперечували можливості збереження перевірених часом, дієвих та ефективних традиційних підходів щодо медичної освіти, які напрацьовувалися кожною країною окремо та були перевірені десятиріччями практичної роботи представників ії медичних шкіл та наукової роботи ії вчених. Таким чином, ця стратегія розвитку передбачає урахування традиційних підходів, що є специфічними для країни, при інноваційній діяльності в системі медичної підготовки [1].

Більше того, основна частина розвинутих європейських країн, визнаючи та впроваджуючи уніфіковану кредитно-модульну систему оцінювання знань (European Credit Transfer System, ECTS), паралельно зберегла традиційні для своїх країн системи навчання та оцінювання знань студентів і спеціалістів (у вигляді науково-освітніх програм підготовки спеціалістів різного рівня, престижність та дієвість яких визначається в авторитетних міжнародних рейтингах університетів Тор 500, тощо). Отже, керуючись перевіреними підходами до надання та оцінювання знань і певною мірою впроваджуючи нові підходи, представники вищої медичної освіти багатьох розвинених країн Європи (наприклад, Норвегії) не втратили багаторічних результатів роботи та досягнень своїх медичних шкіл, одночасно розробивши нові

() К. А. Зайцева, В. С. Василик, П. С. Жученко 
механізми до представлення результатів оцінювання за ECTS.

Явища асистенціалізму (політики фінансової чи соціальної допомоги, яка спрямована на усунення симптомів, а не причин недосконалості соціальної організації певного виду діяльності) в медичній освіті є антидіалоговими за своєю сутністю та небезпечними, тому що не формують відповідальності, не надають можливостей для прийняття рішень та якісного втілення реформ, що стимулює пасивність виконавців реформ на всіх рівнях (незалежно від того, чи супровід реформи - "assistance" - надходить з закордонного чи з внутрішнього джерела) [2]. Проте на сьогодні неможливо заперечувати, що вони мали місце в нашій країні, особливо на початковому етапі реформи медичної освіти і практичної охорони здоров'я. На те були достатньо серйозні та об'єктивні причини - перехідний стан соціально-економічного устрою в країні, що спричинив зміни в організації медичної освіти та практики, а не тільки так званий “комплекс меншовартості” в менталітеті українців, хоча він також мав місце як експліцитно (точно визначеним, прямо та відкрито висловленим), так і імпліцитно (не висловлений прямо та відкрито, не визначений точно) [3, 4], й відіграв свою негативну роль на початковому етапі змін у системі медичної освіти та практики. Зазначене не означає ігнорування ресурсів міжнародного співробітництва, однак науково-практичні розробки створюються в певних соціально-економічних, соціально-культурних i етно-культурних умовах, тобто в певному середовищі (контексті), тому зазнають впливу цього середовища, а отже, можуть потребувати адаптації чи навіть модифікації в інших умовах. Останнім часом самі автори міжнародних проектів визнають доцільність перевірки ефективності запропонованих ними підходів у різних контекстах із урахуванням пріоритетів середовища, в якому вони впроваджуються - "in the setting priorities" $[5,6]$.

Перспективним напрямком реформаторської діяльності у сфері медичної освіти сьогодення є постійний діалог між структурами, які визначають стратегічні напрямки розвитку медицини, та структурами і спеціалістами, які мають тактично втілювати медичну

\section{Лiтература}

1. European University Association, Doctoral Programmes in Europe's Universities: achievements and challenges. Report prepared for European universities and Ministers of Higher education. - Brussels : EUA, 2007. - 43 pp.

2. Фрейре Пауло. Формування критичної свідомості / реформу, щоб уникнути недостатньої автономії останніх, недостатнього контролю над процесом впровадження реформ та недостатнього зворотного зв' язку їх із реформаторами $[3,4]$. Як відомо з базових положень соціальної психології, відсутність особистої автономії у виконавця завдання, неможливість контролю над виконуваним завданням з боку самого виконавця, відсутність зворотного зв'язку між ним i тими, хто поставив завдання і контролює процес його виконання, породжує стресову ситуацію - тобто напруження механізмів адаптації до нових викликів середовища із негарантованою і непрогнозованою ефективністю процесів цієї адаптації [7]. Водночас надмірно вузька спеціалізація людини у певній сфері діяльності обмежує їі світогляд, знижує здатність критично мислити тазбільшує пасивність при впровадженні нових підходів [2].

Глобальне прискорення процесу оновлення науково-практичної інформації, скорочення періоду напіврозпаду компетенції спеціаліста (на даний час складає менше 5 років) зумовлюють доцільність створення науково-освітніх програм післядипломної підготовки лікарів, тому що в цьому випадку інформація швидше потраплятиме з наукової лабораторії до осіб, яких навчають, i, відповідно, до їхніх пацієнтів. Було б доцільним зробити створення таких програм напрямком роботи науково-медичних шкіл на базі університетських клінік України.

Висновки: 1. Медична освіта повинна формувати в усіх суб' єктів навчального процесу (тих, хто викладає, i тих, хто навчається) в медичному університеті не тільки здатність спільного обговорення проблем свого контексту, а й втручання в цей контекст - на основі гарантії бути почутими. Цей принцип $\epsilon$ важливим елементом світогляду сучасних медиків.

2. Програми післядипломної підготовки лікарів, створені науково-медичними школами на базі університетських клінік, дозволять вдосконалити післядипломний етап практичної підготовки лікарів, якщо передбачатимуть застосування зарубіжних методик із ретельною оцінкою доцільності застосування прозахідних підходів в умовах України, а не їх автоматичне наслідування та “імпортування”.

Фрейре Пауло ; пер. $з$ англ. О. Дем’янчук. - К. : Юніверс, 2003. $-176 \mathrm{c}$.

3. Wiberg Matti. Political autonomy: Ambiguities and clarifications / Wiberg Matti // Autonomy: Applications and implications ; Edited by Markku Suksi. - Hague/London/ 
Boston: Martinus Nijhoff Publishers, 1998. - P. 43-57.

4. Bullain Inigo. 1998. Autonomy and the European Union // Autonomy: Applications and implications [ed. Markku Suksi].

- Hague/London/Boston: Martinus Nijhoff Publishers, 1998.

-P. 343-356.

5. Skovdal M. Orphan competent communities: a framework for community analysis and action / M. Skovdal, C. Campbell //

/ Vulnerable Children and Youth Studies. -2009.- P. 1-12.

6. Snipstad M. B. Child Rights or Wrongs: Dilemmas in Implementing Support for Children in the Kilimanjaro Region
(Tanzania) in the Era of Globalized AIDS Approaches / M. B. Snipstad, G. T. Lie, D. Winje // Parenting after the century of the child: travelling ideals, institutional negotiations \& individual responses ; Edited by T. Thelen \& H. Haukanes Farnham: Ashgate, 2010.- P. 205-222.

7. Купер Кэри Л. Организационный стресс. Теории, исследования и практическое применение / Купер Кэри Л., Дэйв Филипп Дж., О’ Драйсколл Майкл П. ; пер. с англ. Х. : Изд-во Гуманитарный центр, 2007. -336 с. 